\title{
The Impact of Visceral Fat Accumulation on Laparoscopy-Assisted Distal Gastrectomy for Early Gastric Cancer
}

\author{
Junji Ueda, Hitoshi Ichimiya and Masao Tanaka \\ Department of Surgery and Oncology, Kyushu University, Fukuoka \\ Department of Surgery, Hamanomachi Hospital, Fukuoka
}

Japan

\section{Introduction}

Gastric cancer is one of the most common malignancies in Japan. Laparoscopic techniques have been used for the treatment of cancer in several organs, and laparoscopy-assisted distal gastrectomy (LADG) has recently been widely accepted for the treatment of early gastric cancer in Japan (Shimizu et al., 2003; Noshiro et al., 2005; Kitano et al., 2007). The potential benefits of LADG include less pain, less operative blood loss, earlier resumption of oral intake and shorter hospital stay compared to conventional open surgery (Adachi et al.,2000; Shimizu et al., 2000; Kitano et al., 2002).

Obesity is a rapidly growing epidemic, and has been considered a risk factor for postoperative complications (Dhar et al., 2000; Inagawa et al., 2000). Special caution may be required when performing laparoscopic surgery on obese patients. Although several studies have reported that obesity adversely affects the technical difficulty and postoperative outcome of laparoscopic surgery (Noshiro et al., 2003; Senagore et al., 2003; Yasuda et al., 2004), some recent studies have reported that obesity does not adversely affect these factors (Leroy et al.; 2005; Kim et al., 2006). The impact of obesity on the technical feasibility and outcome of laparoscopic surgery remains controversial.

Obesity is characterized by an excess of visceral fat (VF) and subcutaneous fat (SF) accumulation. In Japan, the prevalence of obesity, defined by the World Health Organization as body mass index $(\mathrm{BMI}) \geq 30 \mathrm{~kg} / \mathrm{m}^{2}$, is only $2-3 \%$, in contrast to $30-35 \%$ in the United States (Yoshiike et al., 2002; Kanazawa et al., 2005; Ogden et al., 2006). However, recent papers have shown that Japanese have more VF tissue than Caucasians (Tanaka et al., 2003; Kadowaki et al., 2006). The accumulation of VF is thought to be one of the important factors affecting operative difficulty in laparoscopic gastric surgery. Although many surgeons feel that excess VF accumulation increases operative difficulty, the relationship between fat accumulation and operative difficulty has not been fully studied (Tsukada et al., 2004; Seki et al., 2007).

It is well known that excess VF accumulation is associated with cardiovascular disease, diabetes and hypertension (Fujioka et al., 1987; Kanai et al., 1990; Despres \& Lemieux, 2006). We hypothesized that VF accumulation is also associated with technical difficulty and postoperative outcome of LADG. In this study, we evaluated the impact of VF accumulation on the technical difficulty and postoperative outcome of LADG (Ueda et al., 2009). 


\section{Patients and methods}

\subsection{Patients}

The medical charts of 34 consecutive patients who had a preoperative diagnosis of early gastric cancer and underwent LADG in our hospital (Hamanomachi Hospital, Fukuoka, Japan) between November 2000 and November 2006 were analyzed. Three patients who underwent simultaneous LADG and cholecystectomy and one patient whose preoperative computed tomography (CT) was not performed in our hospital were excluded from the study. LADG was performed for lesions located in the antrum or body of the stomach. As the ability to perform extended lymphadenectomy is limited in LADG, the procedure was performed only for lesions thought preoperatively not to be infiltrating beyond the submucosal layer. The depth of infiltration of the lesion was assessed preoperatively using radiography, endoscopy and endoscopic ultrasonography.

\subsection{Measurement of visceral and subcutaneous fat accumulation}

VF and SF accumulation were quantified on preoperative abdominal CT images. The area of VF and SF tissue on cross-sectional CT at the level of the umbilicus was measured using FatScan software (N2 system corporation, Kobe, Japan) (Fig. 1A and 1B) (Yoshizumi et al., 1999). Patients were divided into high and low VF accumulation groups based on the area of VF tissue, according to the criteria for VF accumulation recommended by the Japan Society of the Study of Obesity. Patients in the high VF accumulation group had an area of VF tissue $\geq$ $100 \mathrm{~cm}^{2}$, and patients in the low VF accumulation group had an area of VF tissue $<100 \mathrm{~cm}^{2}$.

\subsection{Surgical procedures}

All LADGs were performed with 4 or 5 trocars under a pneumoperitoneum of $8-12 \mathrm{mmHg}$. Operative techniques consisted of the following procedures as described in other papers (Noshiro et al., 2005; Kitano et al., 2007): 1) laparoscopic dissection of the lesser and greater omentum, and ligation and division of the vessels to mobilize the stomach, 2) resection of the distal two-thirds of the stomach with $\mathrm{D} 1+\alpha, \mathrm{D} 1+\beta$, or $\mathrm{D} 2$ lymph node dissection based on the Guidelines of the Japan Gastric Cancer Association, and 3) Billroth I reconstruction through a $5-8 \mathrm{~cm}$ minilaparotomy incision.

\subsection{Statistical analysis}

We obtained the following clinical data from medical charts: age, sex, concurrent illnesses, tumor characteristics, operation time, operative blood loss, number of dissected lymph nodes, time to first flatus, time to resumed food intake, length of fever, white blood cell count, serum C-reactive protein (CRP) level and postoperative complications. Values were expressed as mean \pm SD. Correlation between the area of fat accumulation and operative difficulties was analyzed by Pearson's correlation test. Differences between the two groups of patients were analyzed by either Student t-test or $X^{2}$ test. All statistical analyses were performed with StatView 5.0 software (SAS Institute, Cray, CA). A $P$ value of $<0.05$ was considered statistically significant.

\section{Results}

\subsection{Correlation between fat accumulation and operative difficulty}

To investigate the effect of fat accumulation on the technical difficulty of performing LADG, the correlation between fat accumulation and operation time was analyzed. The area of VF 


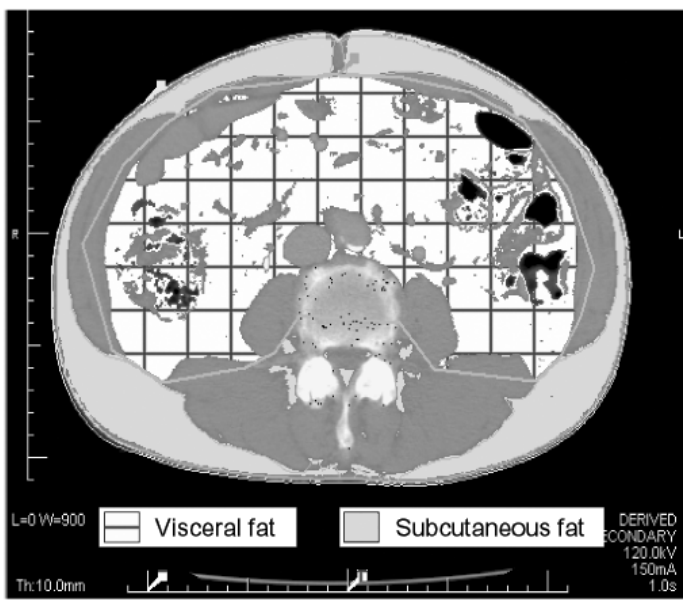

Fig. 1a.

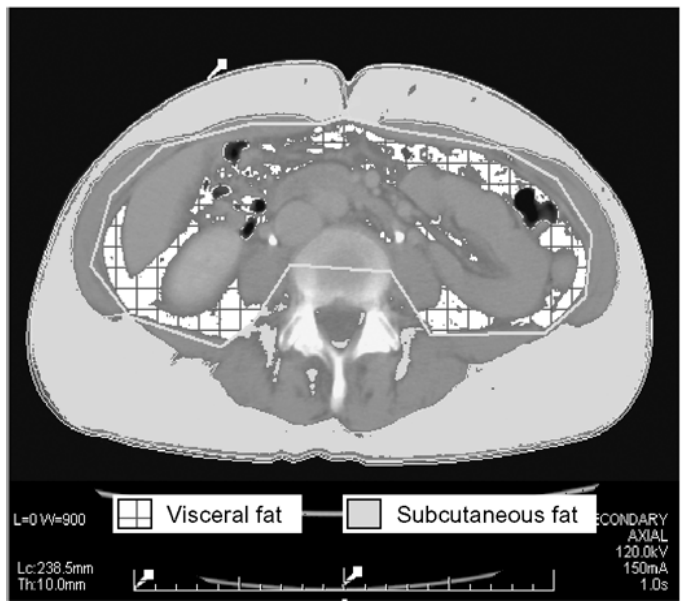

Fig. 1b.

tissue was strongly and significantly correlated with operation time $\left(P=0.002, \mathrm{R}^{2}=0.285\right.$, Fig. 2A), but the area of SF tissue was not correlated with operation time $\left(P=0.229, \mathrm{R}^{2}=\right.$ 0.052, Fig. 2B). The correlation between fat accumulation and operative blood loss was also analyzed. The area of VF tissue was strongly and significantly correlated with operative blood loss $\left(P=0.0003, \mathrm{R}^{2}=0.365\right.$, Fig. $\left.2 \mathrm{C}\right)$, but the area of SF tissue was not significantly correlated with operative blood loss $\left(P=0.060, \mathrm{R}^{2}=0.120\right.$, Fig. 2D). These findings suggest that VF accumulation rather than SF accumulation may be a risk factor in LADG. Because BMI has commonly been used as a marker of obesity, the correlation between BMI and operation time or operative blood loss was also analyzed. BMI was significantly correlated with both operation time and operative blood loss $\left(P=0.044, \mathrm{R}^{2}=0.138\right.$, and $P=0.042, \mathrm{R}^{2}=$ 0.139, respectively) (Fig. 2E and 2F). VF accumulation was, however, much more strongly correlated with both operation time and operative blood loss than BMI. These data suggest that VF accumulation may be strongly associated with operative difficulty in LADG. 


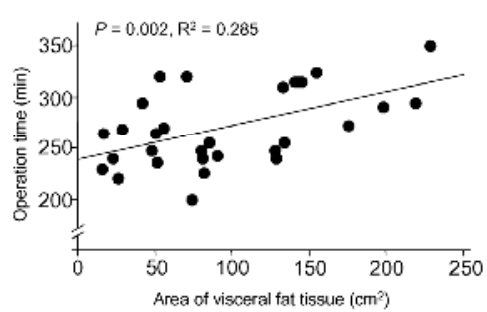

A

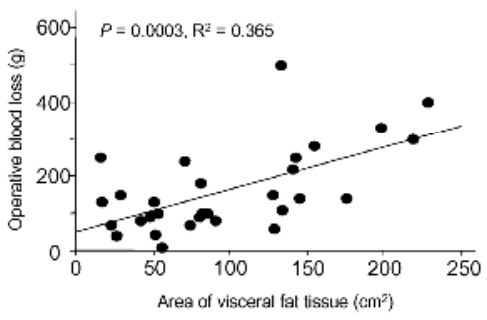

C

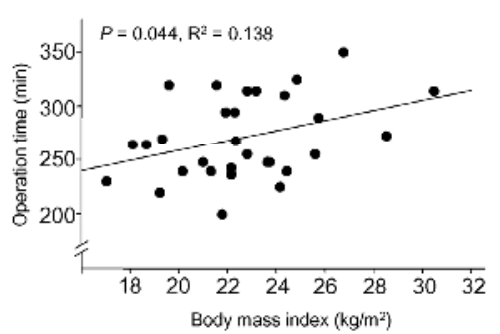

$\mathrm{E}$

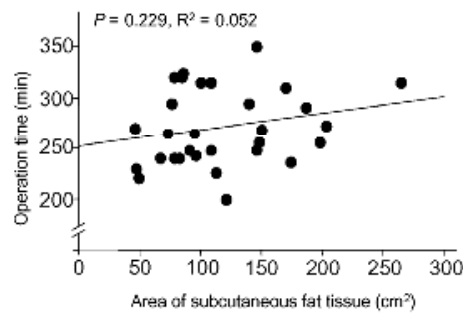

B

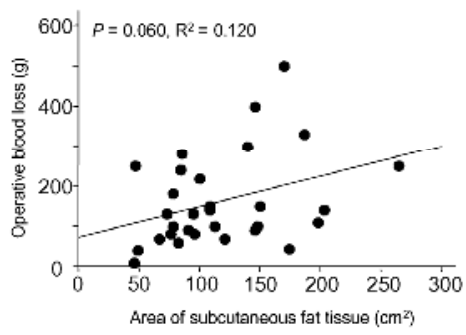

$\mathrm{D}$

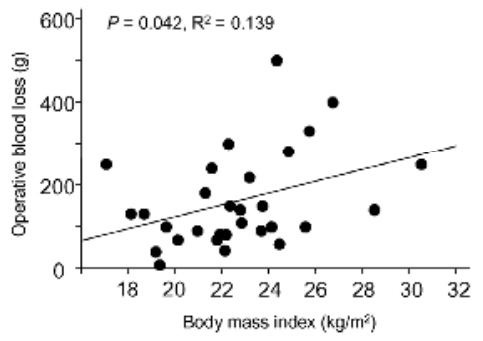

$\mathrm{F}$

Fig. 2.

\subsection{The impact of VF accumulation on operative difficulty and outcome of LADG}

To confirm the impact of VF accumulation on LADG, patients were divided into high VF accumulation $\left(160.4 \pm 35.9 \mathrm{~cm}^{2}\right)$ and low VF accumulation $\left(53.9 \pm 24.9 \mathrm{~cm}^{2}\right)$ groups. Operative difficulties, operation time, operative blood loss, number of dissected lymph nodes, time to first flatus, time to food intake, duration of fever $\left(>37.5^{\circ} \mathrm{C}\right)$, white blood cell count on day 1 and 7, serum CRP level on day 1 and 7, postoperative complications, and conversion to laparotomy were compared between the two groups. Age, concurrent illnesses, tumor location, tumor size, tumor type, depth of tumor infiltration, and lymph node metastases were similar between the groups. The male to female ratio was significantly higher in the high VF accumulation group than the low VF accumulation group (Table 1). 
The operative outcomes are given in Table 2. Operation time was significantly longer in the high VF accumulation group than the low VF accumulation group (294 \pm 34 minutes versus $255 \pm 32$ minutes, $P=0.003$ ). Operative blood loss was also significantly higher in the high VF accumulation group than the low VF accumulation group ( $240 \pm 129$ g versus $109 \pm 64 \mathrm{~g}, P=0.001)$. There was no significant difference in the number of dissected lymph nodes, time to first flatus, time to food intake and duration fever between the groups. White blood cell count on day 7 and serum CRP level on day 1 and 7 were significantly higher in the high VF accumulation group than the low VF accumulation group. The frequency of postoperative complications and conversion to laparotomy was not significantly different between the groups, but major complications (anastomotic leakage) and conversion to laparotomy occurred only in the high VF accumulation group. There were no recurrences or deaths due to cancer during the follow-up period (range: 8 75 months, mean: 32 months).

\section{Discussion}

The present study showed a significantly longer operation time and significantly more operative blood loss in patients with high VF accumulation than with low VF accumulation. However, time to first flatus, time to food intake, duration of fever elevation and postoperative complications were similar in the two groups. There were no operative deaths or requirements for blood transfusion in either group. These results suggest that LADG is as safe and beneficial for patients with high VF accumulation as for patients with low VF accumulation.

In Japan, dietary changes favoring Western eating habits may have resulted in an increased rate of obesity in the population. BMI has been increasing in Japanese patients with gastric cancer (Kubo et al., 2005). Obesity is characterized by an excess of fat accumulation, and VF accumulation has been reported to be associated with obesity-related diseases such as cardiovascular disease, diabetes and hypertension (Fujioka et al., 1987; Kanai et al., 1990; Despres \& Lemieux, 2006). VF accumulation may also be of great interest to surgeons, who consider excess fat accumulation to be a risk factor because of the limited visualization of surgical fields and increased difficulty of dissecting vessels. In this study, both operation time and operative blood loss were strongly correlated with VF accumulation, even though VF accumulation did not affect the operative death rate or postoperative complication rate. Our data suggests that VF accumulation may be a risk factor for operative difficulty in LADG. Two procedures were converted to open laparotomy, one because of difficulty isolating the root of the right gastroepiploic vessels in abundant fatty tissue, and the other because of difficulty in performing appropriate lymphadenectomy around the common hepatic vessels due to abundant fatty tissue. It is also recently reported that visceral fat accumulation increase operation time in laparoscopic resection of a rectosigmoid carcinoma (Seki et al., 2007). These data strongly supports the surgical opinion that VF accumulation is a risk factor in laparoscopic surgery.

Although the obese population is increasing, severely obese patients are still uncommon in Japan compared to Europe and the United States. None of the patients in our study were severely obese, with the maximum BMI being $31 \mathrm{~kg} / \mathrm{m}^{2}$ and the maximum VF being 230 $\mathrm{cm}^{2}$. VF accumulation in severely obese patients may affect postoperative complications. 
The effect of VF accumulation in severely obese patients undergoing LADG should be further investigated.

Interestingly, the postoperative CRP and white blood cell count were significantly higher in the high VF accumulation group than the low VF accumulation group. VF accumulation is considered to contribute to systemic inflammation (Lyon et al., 2003). It has been shown recently that adipose tissue secretes inflammatory cytokines such as tumor necrosis factoralpha (TNF- $\alpha$ ) and interleukin 6 (IL-6), and that IL-6 production by human adipose tissue increases with obesity (Ronti et al., 2006). Gletsu et al. demonstrated recently that IL-6 content in adipose tissue increased dramatically after laparoscopic surgery, especially in VF tissue, and that plasma IL- 6 concentration is strongly correlated with IL-6 content in adipose tissue (Gletsu et al., 2006). Our data suggests that VF accumulation may play an important role in postoperative inflammation after LADG.

\section{Conclusions}

In conclusion, LADG for the treatment of early gastric cancer is as safe and beneficial for patients with high VF accumulation as for patients with low VF accumulation. VF accumulation may, however, be a risk factor in LADG because VF accumulation had a strong correlation with both operation time and operative blood loss. VF accumulation should be considered as a possible risk factor when making the decision to perform LADG.

\section{References}

Adachi Y. et al. (2000). Laparoscopy-assisted Billroth I gastrectomy compared with conventional open gastrectomy. Arch Surg 135(7):806-10.

Despres JP \& Lemieux I. (2006) Abdominal obesity and metabolic syndrome. Nature 444(7121):881-7.

Dhar DK. et al. (2000). Body mass index determines the success of lymph node dissection and predicts the outcome of gastric carcinoma patients. Oncology 2000; 59(1): 18-23.

Fujioka S. et al. (1987). Contribution of intra-abdominal fat accumulation to the impairment of glucose and lipid metabolism in human obesity. Metabolism 36(1): 54-9.

Gletsu N. et al. (2006). Increased plasma interleukin 6 concentrations and exaggerated adipose tissue interleukin 6 content in severely obese patients after operative trauma. Surgery 140(1):50-7

Inagawa S. et al. (2000). Effect of fat volume on postoperative complications and survival rate after D2 dissection for gastric cancer. Gastric Cancer 3(3):141-144.

Kadowaki T. et al. (2006). Japanese men have larger areas of visceral adipose tissue than Caucasian men in the same levels of waist circumference in a population-based study. Int J Obes 30(7):1163-5.

Kanai H. et al. (1990). Close correlation of intra-abdominal fat accumulation to hypertension in obese women. Hypertension 16(5):484-90. 
Kanazawa M. et al. (2005). Criteria and classification of obesity in Japan and Asia-Oceania. World Rev Nutr Diet 94:1-12.

Kim KH. et al. (2006). The impact of obesity on LADG for early gastric cancer. Gastric Cancer 9(4):303-7.

Kitano S. et al. (2002) A randomized controlled trial comparing open vs laparoscopyassisted distal gastrectomy for the treatment of early gastric cancer: an interim report. Surgery 131(1 Suppl):S306-11.

Kitano S.et al. (2007) A multicenter study on oncologic outcome of laparoscopic gastrectomy for early cancer in Japan. Ann Surg 245(1):68-72.

Kubo M. et al. (2005) Increasing body mass index in Japanese patients with gastric cancer. Gastric Cancer 8(1):39-41.

Leroy J. et al. (2005) The impact of obesity on technical feasibility and postoperative outcomes of laparoscopic left colectomy. Ann Surg 241(1):69-76.

Lyon CJ. et al. (2003) Minireview: adiposity, inflammation, and atherogenesis. Endocrinology 144(6):2195-200.

Noshiro H. et al. (2003) Laparoscopy-assisted distal gastrectomy for early gastric cancer: is it beneficial for patients of heavier weight? Ann Surg 238(5):680-5.

Noshiro H. et al. (2005) Laparoscopically assisted distal gastrectomy with standard radical lymph node dissection for gastric cancer. Surg Endosc 19(12):1592-6.

Ogden CL. et al. (2006) Prevalence of overweight and obesity in the United States, 19992004. Jama 295(13):1549-55.

Ronti T. et al. (2006) The endocrine function of adipose tissue: an update. Clin Endocrinol 64(4):355-65.

Shimizu S. et al. (2000) Laparoscopically assisted distal gastrectomy for early gastric cancer: is it superior to open surgery? Surg Endosc 14(1):27-31.

Shimizu S. et al. (2003) Laparoscopic gastric surgery in a Japanese institution: analysis of the initial 100 procedures. J Am Coll Surg 197(3):372-8.

Senagore AJ. et al. (2003) Laparoscopic colectomy in obese and nonobese patients. J Gastrointest Surg 7(4):558-61.

Seki Y. et al. (2007) Evaluation of the technical difficulty performing laparoscopic resection of a rectosigmoid carcinoma: visceral fat reflects technical difficulty more accurately than body mass index. Surg Endosc 21(6):929-34.

Tanaka S. et al. (2003) Ethnic differences in abdominal visceral fat accumulation between Japanese, African-Americans, and Caucasians: a meta-analysis. Acta Diabetol 40 Suppl 1:S302-4.

Tsukada K. et al. (2004) Body fat accumulation and postoperative complications after abdominal surgery. Am Surg 70(4):347-51.

Ueda J. et al. (2009) The impact of visceral fat accumulation on laparoscopy-assisted distal gastrectomy for early gastric cancer. J Laparoendosc Adv Surg Tech 19(2): $157-62$.

Yasuda K. et al. (2004) Laparoscopy-assisted distal gastrectomy for early gastric cancer in obese and nonobese patients. Surg Endosc 18(8):1253-6.

Yoshiike N. et al. (2002) Epidemiology of obesity and public health strategies for its control in Japan. Asia Pac J Clin Nutr 11 Suppl 8:S727-31. 
Yoshizumi T. et al. (1999) Abdominal fat: standardized technique for measurement at CT. Radiology 211(1):283-6. 


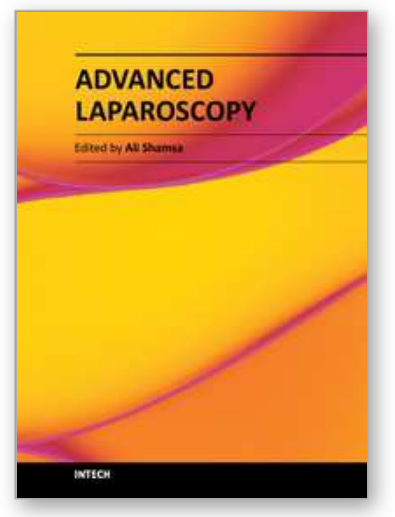

\author{
Advanced Laparoscopy \\ Edited by Prof. Ali Shamsa
}

ISBN 978-953-307-674-4

Hard cover, 190 pages

Publisher InTech

Published online 30, September, 2011

Published in print edition September, 2011

The present book, published by InTech, has been written by a number of highly outstanding authors from all over the world. Every author provides information concerning treatment of different diseases based on his or her knowledge, experience and skills. The chapters are very useful and innovative. This book is not merely devoted to urology sciences. There are also clear results and conclusions on the treatment of many diseases, for example well-differentiated papillary mesothelioma. We should not forget nor neglect that laparoscopy is in use more extensively than before, and in the future new subjects such as use of laparascopy in treatment of kidney cysts, simple nephrectomy, pyeloplasty, donor nephrectomy and even robotic laparoscopy will be researched further.

\title{
How to reference
}

In order to correctly reference this scholarly work, feel free to copy and paste the following:

Junji Ueda, Hitoshi Ichimiya and Masao Tanaka (2011). The Impact of Visceral Fat Accumulation on Laparoscopy- Assisted Distal Gastrectomy for Early Gastric Cancer, Advanced Laparoscopy, Prof. Ali Shamsa (Ed.), ISBN: 978-953-307-674-4, InTech, Available from: http://www.intechopen.com/books/advancedlaparoscopy/the-impact-of-visceral-fat-accumulation-on-laparoscopy-assisted-distal-gastrectomy-for-earlygastric

\section{INTECH}

open science | open minds

\author{
InTech Europe \\ University Campus STeP Ri \\ Slavka Krautzeka 83/A \\ 51000 Rijeka, Croatia \\ Phone: +385 (51) 770447 \\ Fax: +385 (51) 686166 \\ www.intechopen.com
}

\author{
InTech China \\ Unit 405, Office Block, Hotel Equatorial Shanghai \\ No.65, Yan An Road (West), Shanghai, 200040, China \\ 中国上海市延安西路65号上海国际贵都大饭店办公楼 405 单元 \\ Phone: +86-21-62489820 \\ Fax: +86-21-62489821
}


(C) 2011 The Author(s). Licensee IntechOpen. This chapter is distributed under the terms of the Creative Commons Attribution-NonCommercialShareAlike-3.0 License, which permits use, distribution and reproduction for non-commercial purposes, provided the original is properly cited and derivative works building on this content are distributed under the same license. 